\title{
EFFECT OF BREED, BODY CONDITION SCORE AND AGE ON SOME ECONOMIC TRAITS OF LOCAL FLOCKS EWES
}

\author{
Salim Omar Raoof \\ Animal Resources Dept., College of Agriculture, Salahaddin University, Erbi- Iraq. \\ E-mail:salmomarraoof@yahoo.com
}

\begin{abstract}
This study aimed to estimate the effect of breed, Body Condition Score (BCS) and age on some economic traits of local flock's ewes. The ewes studied in the present investigation represent three local breeds (53 karadi, 44 Awassi and 47 Mamesh) bred in Erbil plain during the period from January/ 2009 to June /2010.The results showed a highly significant breed effect $(\mathrm{p}<0.01)$ on all the studied traits. Mamesh ewes surpassed both Karadi and Awassi ewes in milk yield (102.269, 88.254 and 92.684 $\mathrm{kg}$ ), respectively, besides the lambs of the same breed were superior in birth weight $(4.885 \mathrm{~kg})$ and weaning weight $(27.612 \mathrm{~kg})$ compared with karadi and Awassi lambs. Greasy fleece weights of the Karadi, Awassi and Mamesh ewes were 2.220, 1.829 and $2.585 \mathrm{~kg}$ respectively. The superiority of Mamesh ewes were found to be highly significant $(\mathrm{p}<0.01)$. The study also revealed that the (BCS) exerts an important effect on milk yield, greasy fleece weight and birth weight. Ewes with (BCS) 4 showed a higher milk yield $(102.883 \mathrm{~kg})$ as comparing with ewes having (BCS) $3(95.083 \mathrm{~kg}$ ) and that having $(\mathrm{BCS}) 2(86.391 \mathrm{~kg})$.Correlation coefficient highly significant $(\mathrm{p}<0.01)$ between birth weight and milk yield was 0.32 and between birth weight and weaning weight was 0.38 and between ewes body weight and greasy fleece weight was 0.43 .

Keywords: Breed, BCS, Milk production, Birth\& weaning weights, Correlation.
\end{abstract}

Received: 5/5/2013, Accepted: 11/11/2013.

\section{INTRODUCTION}

Iraqi local ewes are characterized by a lower meat, milk and wool production. The lower productivity can be attributed to their genetic merits and their capabilities and fitness to survive under hard environmental conditions, which found to be related to their lower production performance (Al-Rawi, 1995). This study was conducted at Erbil plains. Karadi breed is dominated in Erbil plain as well as in northern Iraq (20\%), where as the Awassi breed is the most popular local breed in the middle of Iraq (65\%) (Alkass and Juma, 2005). Mamesh breed is an Iranian sheep imported to Erbil about five years ago(Raoof, 2009). All breeds are not specialized for definite production, they are multipurpose breeds for meat, milk and wool production. Milk yield is the most important factor affecting lamb growth during pre-weaning period. Accordingly, higher milk yield positively affect lamb growth and the lamb attaining weaning age at higher weaning weights. Sheep are considered one of the main sources of supplementing the best red meat to the Iraqi consumers. Lambs higher growth rate reflect their ability to produce more milk and meat production at the succeeding periods. Moreover, body weights at different ages are considered a strong indicator of growth that can be used as selection criteria for an early evaluation and selection of the best flock individuals (Falconer, 1989). All local Fat -tailed breeds are classified as a coarse wool breeds used for carpets made. This study was carried out to investigate the effects of different local ewes breeds and (BCS)and ewes age on birth weight, weaning 
Mesopotamia J. of Agric.

Vol. (45) No. (4) 2017
ISSN: $2224-9796$ (Online)

ISSN: 1815 - 316 X (Print)

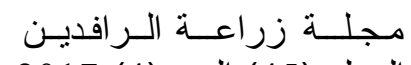

المجلد (45) العدد (4) 2017

weight, milk yield and greasy fleece weight and to estimate of correlation coefficients between the studied traits.

\section{MATERIALS AND METHODS}

One hundred forty four ewes representing three local ewe breeds the Karadi (53), Awassi (44) and Mamesh ewes (47), were used in this study. The ewes were raised at Erbil plain for the period from January 2009 to June 2010.The traits studied include the following: Body Condition Score (BCS) was measured at the beginning of the experiment and monthly during lactation season, wool shearing and at birth, weaning weights recording. Body Condition Score (BCS) was measured by a hand - touching of the back bone at the loin area near the last body rib over the kidney by a trained expert technician. The (BCS) was classified to five grade groups starting by $1^{\text {st }}$ score for the very weak to the $5^{\text {th }}$ score for the very fat (MLC, 1988). The ewes were classified into three groups according to (BCS) as follows:

1-Ewes group with a (BCS) of (2).

2- Ewes group with a (BCS) of (3).

3- Ewes group with a (BCS) of (4).

Milk yield was recorded after $15^{\text {th }}$ days of birth using hand-milking once every month till the drying period100g/d (ICAR, 1995). Birth and weaning (90 days) weights were recorded. Greasy fleece weight and body weight were recorded at shearing $\left(1^{\text {st }}\right.$ May) by hand-shearing. The ewes were allowed to graze wheat and barley residues with a supplement of 600-750g concentrate diet composed of barley, wheat bran and corn. Wheat straw was offered ad libitum. Mineral blocks and clean water were also supplemented during the period of the study. All the animals were vaccinated, dipped and drenched according to the routine program applied for each local flock. A (General Linear Model) GLM used for the statistical analysis of the data .Dancan multiple range test (Dancan, 1955) was preformed for the mean differences comparisons. A procedure of the statistical analysis system (SAS, 2005) was used according to the following linear additive model:

$$
\text { Yijklm }=\mu+\mathrm{B}_{i}+\mathrm{C}_{j}+\mathrm{A}_{k}+\mathrm{W}_{l}+\mathrm{e}_{i j k l m}
$$

$\mathrm{y}_{\mathrm{ijk} \mathrm{lm}}$ is the value of any observation in the study.

$\mu$ : Overall mean

$\mathrm{B}_{i}$ :Effect of $\mathrm{i}^{\text {th }}$ breed; $\mathrm{i}=$ karadi, Awassi and Mamesh.

$\mathrm{C}_{l:}$ : Effect of $\mathrm{j}^{\text {th }}$ body condition score; $\mathrm{j}=2,3$ and 4 .

$\mathrm{A}_{k}$ : Effect of $\mathrm{k}^{\text {th }}$ age of ewe; $\mathrm{k}=2.5,3.5,4.5$ and $\geq 5.5$ years.

$\mathrm{W}_{l}$ : Effect of $1^{\text {th }}$ ewes weight; $1=40-49,50-59$ and $\geq 60$.

$\mathrm{e}_{i j k l m}$ :Random error associated with the $\mathrm{ijklm}{ }^{\text {th }}$ observation, assumed to be

NID $\left(0, \partial^{2} \mathrm{e}\right)$. Also the coefficient correlation between the traits were estimated.

\section{RESULTS AND DISCUSSION}

Milk production: The study of genetic variation between breeds for milk yield under any environmental conditions is of a vital importance in determining the most suitable breed that could be adapted to the conditions of that particular environment. The results showed that there were a highly significant breed effect on milk yield, and there were 88.254, 92.684 and $102.269 \mathrm{~kg}$ for (karadi, Awassi and Mamesh) respectively (table 1). It was evident that the highest milk yield was in Mamaesh breed $102.269 \mathrm{~kg}$ and the lowest value was in Karadi breed $88.254 \mathrm{~kg}$ (table 1). While, the result showed no significant differences were observed between Karadi and Awassi breeds in milk yield. The results were in agreement with (Al-Samrai et al., 2010and Al-Juwari, 2011), 
Mesopotamia J. of Agric.

Vol. (45) No. (4) 2017
ISSN: $2224-9796$ (Online)

ISSN: 1815 - 316 X (Print)

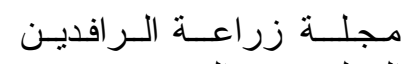

المجلد (45) العدد (4) 2017

when in local Awassi and Turkish ewes. The effect of(BCS) on this trait was found to be highly significant. Ewes with the (BCS) 4 showed a highest milk yield (102.883) $\mathrm{kg}$. And the lowest milk yield was that of ewes with (BCS) 2, (86.391) kg. Again the results of this study showed a similar trend to that reported by (El-Sahel et al., 1999 and Raoof, 2003). Age had a significant effect on milk yield. Ewes aged 3.5 and 4.5 years produced a higher milk yield of 100.727 and $103.906 \mathrm{~kg}$ respectively, comparing with those aged 2.5 and 5.5 years $(83.256$ and 84.242$) \mathrm{kg}$ respectively. The superiority of the first two age groups was significant. This result could be best attributed to the development and maturity of the mammary gland with the advancement of age till 4.5 years and due to the increase of maternal weights as a result of increasing the digestive canal volume (Owen, 1976). (table1).Correlation coefficient between the milk yield and birth weight was highly significant 0.32 .

Table (1): Means \pm Standard Errors of the effect of breed, (BCS) and age of sheep on total milk production.

\begin{tabular}{|c|c|c|}
\hline Trait factors & No. & $\begin{array}{c}\text { Mean } \pm \text { S.E } \\
(\mathrm{kg})\end{array}$ \\
\hline Breed & & $* *$ \\
\hline karadi & 53 & $88.254 \pm 0.386 \mathrm{~b}$ \\
\hline Awassi & 44 & $92.684 \pm 0.417 \mathrm{~b}$ \\
\hline Mamesh & 47 & $102.269 \pm 0.302 \mathrm{a}$ \\
\hline BCS & & $* *$ \\
\hline 2 & 48 & $86.391 \pm 0.387 \mathrm{c}$ \\
\hline 3 & 56 & $95.083 \pm 0.344 \mathrm{~b}$ \\
\hline 4 & 40 & $102.883 \pm 0.341 \mathrm{a}$ \\
\hline Age of ewe (year) & & $* * 2.256 \pm 0.525 \mathrm{~b}$ \\
\hline 2.5 & 43 & $100.727 \pm 0.386 \mathrm{a}$ \\
\hline 3.5 & 35 & $103.906 \pm 0.376 \mathrm{a}$ \\
\hline 4.5 & 33 & $84.242 \pm 0.650 \mathrm{~b}$ \\
\hline $5.5 \geq$ & 33 & \\
\hline
\end{tabular}

* Significant at $(\mathrm{p}<0.05) * *$ Significant at $(\mathrm{p}<0.01)$

Values within the same column with different superscripts are significantly different

Birth and weaning weight: The results showed a highly significant breed effect on birth weight (table 2). Birth weight of Karadi, Awassi and Mamesh lambs were 3.968, 4.403 and $4.885 \mathrm{~kg}$ respectively. Similar values were reported by (Al-Jalily et al, 2006, Mohammed, 2008, Oramary, 2009, Raoof, 2009and Al-Juwari, 2011). Breed effect on weaning weight was highly significant. The weaning weights of karadi, Awassi and Mamesh lambs were21.956, 23.937and $27.612 \mathrm{~kg}$, respectively. The variation of weaning weights between breeds may be due to the differences of the genetic merits of the breeds, birth weight and the amount of milk available during suckling period . Ewes of (BCS) 3and 4 gave significantly $(\mathrm{P}<0.01)$ highest lamb birth weight $(4.805$ and $4.695 \mathrm{~kg})$, respectively, where as ewes with(BCS) 2 gave the lowest value $3.976 \mathrm{~kg}$. This findings were in an agreement with the results presented by(Raoof, 2003) in Hamdani lambs which indicated an improvement in the productive performers of ewes with the improvement of their (BCS). The effect of (BCS) on weaning weight was not significant. Moreover, the lambs from (BCS) of 3 and 4 gave 
Mesopotamia J. of Agric.

Vol. (45) No. (4) 2017
ISSN: $2224-9796$ (Online)

ISSN: 1815 - $316 \mathrm{X}$ (Print)

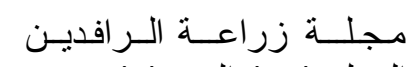

المجلد (45) العدد (4) 2017

the highest weaning weight (25.649 and 25.553) $\mathrm{kg}$, respectively compared with lambs from (BCS) 2 (23.940) $\mathrm{kg}$.Ewes age had a significant effect on birth weight (table 2).Ewes aged 2.5 years gave the lowest lamb birth weight $4.021 \mathrm{~kg}$, where as lambs of the ewes aged 3.5 and 4.5 years gave a significantly higher birth weights of their lambs compared with ewe aged 2.5 and $\geq 5.5$ years, (4.980 and 4.736$) \mathrm{kg}$, respectively(table 2). Raoof (2009) reported similar results. The superiority of lambs from aged ewes in birth weight might be attributed to the increase in uterus size with the advancement of age and to the availability of suitable uterus and environmental conditions and the nutrient needed for better embryo growth and development (Owen, 1976). It was evident that ewe's age effect on lamb weaning weight was significant (table 2). Lambs born from ewes aged 5.5years and more gave the lowest weaning weight $21.128 \mathrm{~kg}$, whereas that from ewes aged 4.5 and 3.5 years gave the highest weaning weight $(27.385$ and 26.286$) \mathrm{kg}$, respectively. This result confirms the findings of (Raoof, 2009) of his study on weaning weight of Mamesh ewe lambs. Correlation coefficient between the birth weight and weaning weight was highly significant 0.32 .

Table (2): Means \pm Standard Error of birth and weaning weights.

\begin{tabular}{|c|c|c|c|c|}
\hline Traits factors & No. & Birth weight Mean \pm S.E $(\mathrm{kg})$ & No. & $\begin{array}{c}\text { Weaning weight } \\
\text { Mean } \pm \text { S.E } \\
(\mathrm{kg})\end{array}$ \\
\hline Breed & & $* *$ & & $* *$ \\
\hline Karadi & 53 & $3.968 \pm 0.023 \mathrm{c}$ & 53 & $21.956 \pm 0.136 \mathrm{~b}$ \\
\hline Awassi & 44 & $4.403 \pm 0.020 \mathrm{~b}$ & 44 & $23.937 \pm 0.115 \mathrm{~b}$ \\
\hline Mamesh & 47 & $4.885 \pm 0.016 \mathrm{a}$ & 47 & $27.612 \pm 0.116 \mathrm{a}$ \\
\hline BCS & & $* *$ & & N.S \\
\hline 2 & 45 & $3.976 \pm 0.017 \mathrm{~b}$ & 45 & $23.940 \pm 0.121 \mathrm{a}$ \\
\hline 3 & 49 & $4.805 \pm 0.019 \mathrm{a}$ & 49 & $25.649 \pm 0.137 \mathrm{a}$ \\
\hline 4 & 50 & $4.695 \pm 0.021 \mathrm{a}$ & 50 & $25.533 \pm 0.160 \mathrm{a}$ \\
\hline Age of ewe (year) & & $*$ & & $*$ \\
\hline 2.5 & 37 & $4.021 \pm 0.019 \mathrm{~b}$ & 37 & $23.018 \pm 0.145 \mathrm{~b}$ \\
\hline 3.5 & 38 & $4.980 \pm 0.024 \mathrm{a}$ & 38 & $26.286 \pm 0.187 \mathrm{a}$ \\
\hline 4.5 & 35 & $4.735 \pm 0.035 \mathrm{a}$ & 35 & $27.385 \pm 0.251 \mathrm{a}$ \\
\hline $5.5 \geq$ & 34 & $4.208 \pm 0.027 \mathrm{~b}$ & 34 & $21.128 \pm 0.185 \mathrm{~b}$ \\
\hline
\end{tabular}

* Significant at $(\mathrm{p}<0.055) * *$ Significant at $(\mathrm{p}<0.01)$ N.S Non Significant

Values within the same column with different superscripts are significantly different.

Wool production: Greasy fleece weights of karadi, Awassi and Mamesh ewes were $2.220,1.829$ and $2.585 \mathrm{~kg}$, respectively (table 3 ). Breed effect on this trait was highly significant. Mamesh ewes gave a higher greasy fleece weight compared with Karadi and Awassi ewes. Nevertheless, the difference between the karadi and Awassi ewes was no significant. The variation of greasy fleece weight between breeds reflects differences in both the body size and the feed conversion efficiency to wool. Altai et al. (2009) obtained similar results in his study on local Awassi and 4 crossbreed Assaf. It is apparent from table (3), that BCS effect on the greasy fleece weight was highly significant. Greasy fleece weight was increased with the improvement of BCS. Greasy fleece weights of ewes with (BCS) of 2,3 and 4 were $1.387,2.612$ and $2.710 \mathrm{~kg}$ respectively. This estimates were similar to that obtained by (El-Sahel et al., 1999). Greasy fleece weight of ewes age 2.5 years was the lowest (1.661)kg where as ewes aged 3.5 and 4.5 years showed a higher greasy fleece weight(2.735 to 2.660$) \mathrm{kg}$ 
Mesopotamia J. of Agric.

Vol. (45) No. (4) 2017
ISSN: $2224-9796$ (Online)

ISSN: 1815 - 316 X (Print)
مجلـــة زراعــة الــر افديـن

المجلد (45) العدد (4) 2017

respectively, (table 3). The higher feed intake of older age ewes increase the efficiency of wool follicles, which affect positively the greasy fleece weight.(Alkass et al., 1996). The ewes having body weights $60 \mathrm{~kg}$ or more showed an increase of 0.666 and $1.281 \mathrm{~kg}$ over those ewes with body weights of 50-59 and 40-49 $\mathrm{kg}$ respectively, (table 3 ). This increase in greasy fleece weight of higher body weight ewes may be attributed to the increase in body size which resulted in a higher surface area and better efficiency of wool production (Lupton, 1994).Our findings agree with the results obtained by Magid (2000). The correlation coefficient between body weight at shearing and greasy fleece weight was $0.43(\mathrm{P}<0.01)$.

Table (3): Mean \pm Standard Error of the wool production $(\mathrm{kg})$.

\begin{tabular}{|c|c|c|}
\hline Trait factors & No & $\begin{array}{c}\text { Mean } \pm \text { S.E } \\
(\mathrm{kg})\end{array}$ \\
\hline Breed & & $* *$ \\
\hline Karadi & 53 & $2.220 \pm 0.020 \mathrm{~b}$ \\
\hline Awassi & 44 & $1.829 \pm 0.022 \mathrm{~b}$ \\
\hline Mamesh & 47 & $2.585 \pm 0.018 \mathrm{a}$ \\
\hline BCS & & $* *$ \\
\hline 2 & 54 & $1.387 \pm 0.020 \mathrm{~b}$ \\
\hline 3 & 45 & $2.612 \pm 0.019 \mathrm{a}$ \\
\hline 4 & 45 & $2.710 \pm 0.015 \mathrm{a}$ \\
\hline Age of ewe(year) & & $* 6$ \\
\hline 2.5 & 44 & $2.735 \pm 0.024 \mathrm{a}$ \\
\hline 3.5 & 38 & $2.660 \pm 0.023 \mathrm{a}$ \\
\hline 4.5 & 37 & $1.977 \pm 0.050 \mathrm{~b}$ \\
\hline $5.5 \geq$ & 25 & $* *$ \\
\hline Weight of ewe at shearing(kg) & & $1.630 \pm 0.016 \mathrm{c}$ \\
\hline $40-49$ & 60 & $2.245 \pm 0.023 \mathrm{~b}$ \\
\hline $50-59$ & 41 & $2.911 \pm 0.018 \mathrm{a}$ \\
\hline $60 \geq$ & 43 &
\end{tabular}

* Significant at $(\mathrm{p}<0.05) * *$ Significant at $(\mathrm{p}<0.01)$

Values within the same column with different superscripts are significant different.

The result of this study showed that there were a highly significant breed and BCS effects on milk yield and birth weight. Mamesh ewes gave a higher greasy fleece weight compared with karadi and Awassi ewes. A corroding to the findings of this study it is recommended to use large numbers of animals for each breed in order to get more accurate informations and to make the results of study feasible and workable. Besides, some other physiological traits (fertility, viability) need to be investigated together with estimating the genetic parameters' of the studied traits.

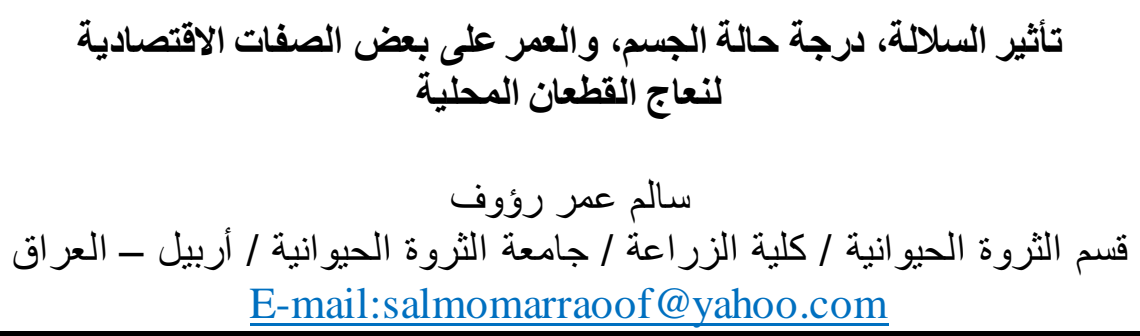




\section{الخلاصة}

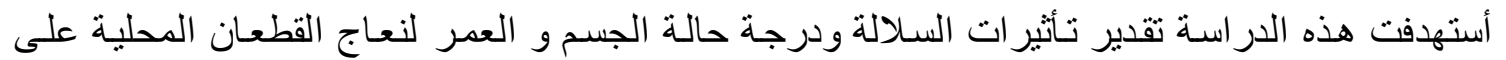

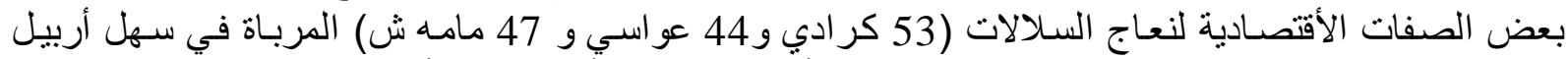

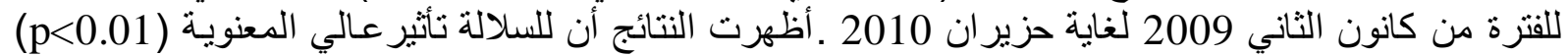

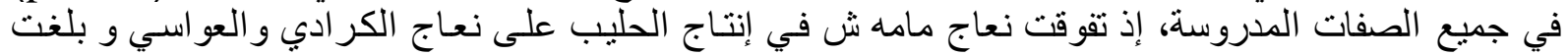

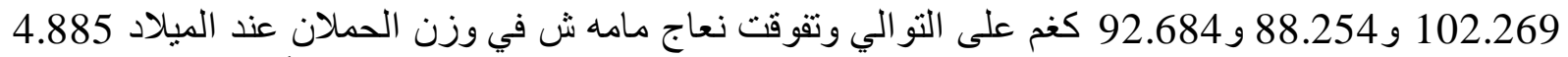

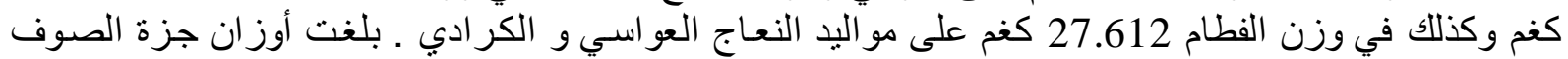

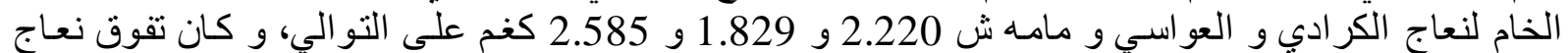

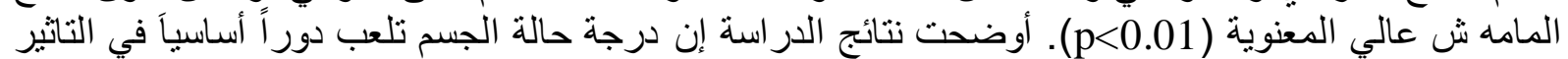

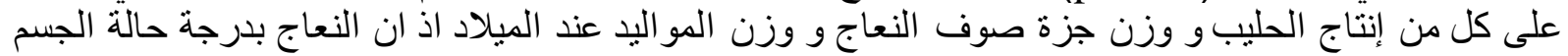

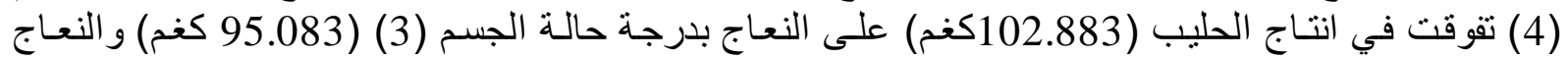

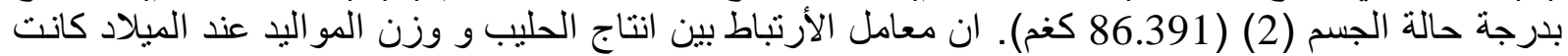

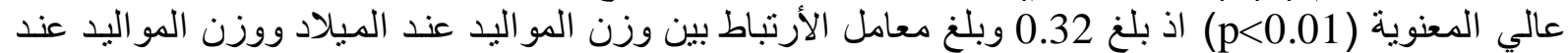

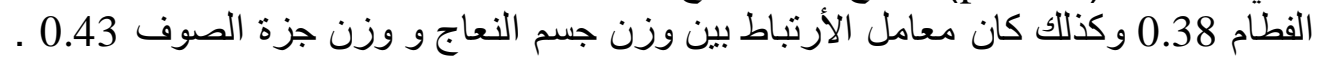

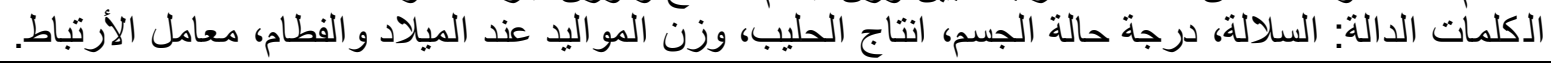

\section{REFERENCES}

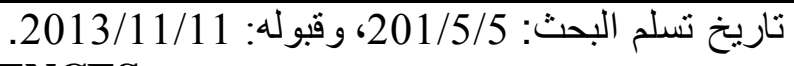

Al-Jalily, Z. F., W. A, Azzawy and Q. S. Mohammed. (2006). The effect of type of birth of ewes and of their lambs on some performance Aspects of Awassi lambs Egyptian Journal of Sheep Goat and Desert Animal Sciences, 1 (1) : 31- 40.

Al-Juwari, M. F. A. (2011). A Study Of Some Genetic And Non-Genetic Factors Affecting Milk Yield, Compositions And Growth Of Lambs In Awassi And Hamdani Ewes. Mesopotamia Journal of Agriculture (39)4:159 -166.

Alkass, J. E and K. H. Juma. (2005). Small Ruminant Breeds of Iraq. In: Characterization of Small Ruminant Breeds in West Asia and North Africa (Ed. L. Linguez). ICARDA. Syria .

Alkass, J. E., H . N. Hermiz and F. S. Badawi. (1996). Pre - weaning performance of lambs resulting from crossing of Finnish landrace with local breeds of sheep in Iraq. IPA Journal Agricultural Research 6 (1):109-117.

Al-Rawi, A. A . (1995). Genetic analysis of crossing local Awassi with Assaf and Turkish Awassi. IPA Journal Agriculture Research. 5 (1): 69-79.

Al-Samrai, W. I. J., R, A, Al-Gelawy., J. V, Elia and H, M, A, Al-Jawbai (2010). Genetic persistency on milk production in local and Turkish Awassi sheep. Diyala Agricultural Science Journal 2 (1): 32 - 43.

Altai, H. M, A., L. D. Alkhozai and A, A. Zoari. (2009). Effect of genetic groups ewes age and weight at shearing on some wool traits. First Journal ofAgriculture Sciences 1(1):41-46.

Anonymous (2005). Statistical Analysis System. Users Guide for Personal Computers, Version 8. 2, SAS. Institute Inc, Cary, NC. USA.

Anonymous, (1988). Feeding The Ewes. Sheep Improvement Service Meat and Livestock Commission. Tech. Rep. No 2 Bletchely.

Anonymous, (1995). International -Regulation For Milk Recording In Sheep. ICAR, Rome.

Duncan, D. B. (1955). Multiple range test. Biometrics. 11:1-42. 
El-Sahel, M. M., A. A. Ali. and M. G. Al-Ngress. (1999). Comparison between the block and blond head Awassi sheep in some productional Characters Research. Journal of Aleppo University . 33:363-376.

Falconer, D. S. (1989). An Introduction To Quantitive Genetics. $3^{\text {rd }}$ Edition Longman House, London.

Lupton, C. J. (1994). Wool and Mohair Production And Processing. In Encyclopedia of Agricultural Science. Academic Press, San Diego. 4:563-594.

Magid. S. A. (2000). Effect of age and sex on some wool characteristics of Awassi sheep . Iraqi Journal of Agriculture Science 5(1):150-155.

Mohammed, L. T. (2008) . Computing Adjustment Factors For Growth Traits In Karadi lambs. MSc. Thesis, College of Agriculture, Duhok University. Iraq.

Oramary, R, A. S. (2009). Genetic Evaluation of karadi Sheep Using Some Productive Traits. PhD. Thesis. College of Agriculture, Duhok University. Iraq.

Owen, J. B . (1976). Sheep Production. London, Bailliere Tindall.

Raoof, S, O. (2003). The effect of body condition score upon some production and reproductive traits of the Hamdani ewes . Iraqi Journal of Agricultural Science $4(4): 54-59$.

Raoof, S. O. (2009). A study of some economic traits of Mamesh sheep in Erbil. Mesopotamia Journal of Agriculture. (37) 1:111- 116. 
Mesopotamia J. of Agric.

Vol. (45) No. (4) 2017
ISSN: 2224 - 9796 (Online)

ISSN: 1815 - 316 X (Print)
مجلــة زراعــة الـر افديـن

المجلد (45) العدد (4) 2017 